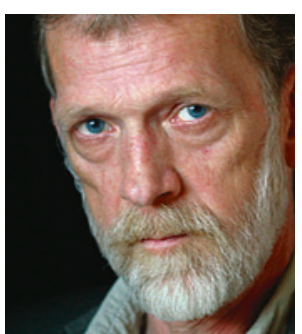

\title{
Retten til å være stolt av sitt arbeid!
}

\section{Forvaltningen av fellesskapets sosiale ansvar og verdier må} avsverge den konkurranseorienterte mål- og resultatstyringsideologien og heller la seg inspirere av Demings systemorienterte kvalitetsledelse.

Historien om dr. W. Edward Deming (1900-93) er helt fantastisk. Han var statistiker og arbeidet med kvalitetskontroll i Bell company. Under den annen verdenskrig ble han innkalt til det amerikanske krigsministeriet for å arbeide med logistikk. Etter krigen var han med i staben til general MacArthur i Japan. Deming ble værende i Japan, og er i dag anerkjent som den som lærte japanerne kvalitetsledelse.

Da Deming som en gammel mann vendte tilbake til USA, var det nesten ingen som hadde hørt om ham. Dette var i jappetiden $f ø r$ finanskrisen i 1987. Deming ble rystet av tilstanden i amerikansk industri og formulerte sine 14 punkter for implementering av kvalitetsledelse samt «fire dødssynder», hvorav mål- og resultatstyring var en.

Driv ut all frykt! lyder Demings første bud. Deming bannlyser mål- og resultatstyring, som han kaller «management by fear». Det kan være karriereødeleggende å kritisere målstyringssystemet. Mål- og resultatstyring har vist seg overlegen når det gjelder å undertrykke intern kritikk og kneble varslerne.

Ifølge Deming er USA dømt til å tape i den globale konkurransen fordi den amerikanske konkurransekulturen ikke i tilstrekkelig grad evner å utnytte de menneskelige ressursene i samfunnet. Deming demonstrerer hvordan det å skape vinnere og tapere ikke forbedrer medarbeiderne eller systemets gjennomsnittlige prestasjoner. Tvert imot. Konkurranseideologien stimulerer en type sosial atferd som hemmer teamet og systemets prestasjoner og innovative evner.

Ifølge Deming må kvalitetsledelse være basert på systemforståelse hos både ledelsen og medarbeiderne. Vi må da ha kunnskaper om hva systemer er og hva målinger og matematikk kan si oss - og ikke si oss - samt en etikk som forteller oss hva som er riktig å gjøre.

Det amerikanske konkurransesamfunnet forbruker medarbeiderne. Målog resultatstyringsideologien karakteriseres av mangel på respekt for medarbeidernes erfaringsbaserte faglige skjønn.

«Folkehelseminister» Jonas Gahr Støre advarer oss mot å diskutere systemet. Deming hevder imidlertid at $85 \%$ av alle problemer i en hvilken som helst verdiproduksjon skyldes systemet, som medarbeiderne ikke er herre over. Systemet er ledelsens ansvar. Bare $15 \%$ av problemene skyldes medarbeiderne. Kostnadsdrivende kontroll- og overvåkningssystemer er stort sett bortkastet, fordi de ikke forbedrer medarbeidernes og systemets prestasjoner. Tvert imot: kontrollsystemene innsnevrer faglig fokus, som igjen leder til kvalitetsforringelse. Det er en dødssynd, ifølge Deming, å utvikle systemer som frarøver medarbeiderne deres soleklare fødselsrett - nemlig retten til å være stolt av sitt arbeid.

Kvalitetsledelse involverer medarbeiderne i en stadig kvalitetsforbedring av produktene gjennom en stadig kvalitetsforbedring av systemet. Kvalitet er prosesseffektivt og kostnadseffektivt fordi det reduserer behovet for dobbeltarbeid og etterarbeid, minimaliserer sløsing, reduserer kontroll- og transaksjonskostnader - og reduserer sykefravær og helseutgifter (!).

Da Deming presenterte sine 14 punkter og fire dødssynder, skapte det umiddelbart furore, men han fikk raskt mange tilhengere som så på hans filosofi som redningen for amerikansk industri. Han lærte kvalitetsledelse til Ford, som raskt oppnådde resultater og gikk forbi GM som den største bilprodusenten på det amerikanske kontinentet. Han lærte kvalitetsledelse til flere sykehus som oppnådde forventede resultater, og Deming anvendte også sin filosofi på tjenesteproduksjonen i offentlig sektor.

Men resultatene blir kortsiktige fordi det amerikanske arbeidslivet ikke er villig til å gi slipp på den inngrodde konkurranseideologien. Målstyringsideologiens omskiftelige ledere evner ikke å ta vare på de umiddelbare resultatene i en langsiktig og bærekraftig bedriftskultur.

Slik sett skulle vi i det egalitære og antiautoritære Norge ha bedre historiske og kulturelle forutsetninger for å utvikle og praktisere kvalitetsledelse i Demings ånd. I samarbeid med forskere og fagbevegelsen er det flere steder i landet gjennomført vellykkede fors $\varnothing$ k med «kvalitetskommuner» inspirert av Demings filosofi.

Kampen mot målstyring og kravet om kvalitetsledelse handler om retten til å være stolt av sitt arbeid. Det er et slikt samfunn vi ønsker å være med på å utvikle og overlate til våre etterkommere.

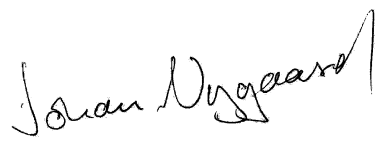

Artikkelen er et utdrag av foredraget Det tverrfaglige systemvitenskapelige paradigmet holdt i Medisinsk-filosofisk forum 12. februar 2013. 